\title{
The South African Journal of Chemistry 1918-2018: A Celebration
}

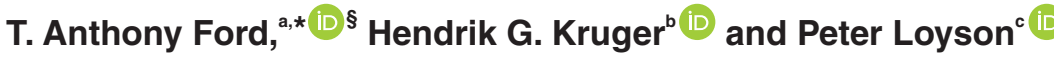 \\ ${ }^{a}$ School of Chemistry and Physics, University of KwaZulu-Natal, Westville Campus, Private Bag X54001, Durban, 4000, South Africa. \\ ${ }^{b}$ Catalysis and Peptide Research Unit, School of Pharmacy, University of KwaZulu-Natal, Westville Campus, Private Bag X54001, \\ Durban, 4000, South Africa. \\ cDepartment of Chemistry, Nelson Mandela University, PO Box 77000, Port Elizabeth, 6031, South Africa.
}

Received 30 May 2019, revised 31 July 2019, accepted 2 August 2019.

\begin{abstract}
In celebration of the centenary of the first publication of the South African Journal of Chemistry, the history of the Journal is traced, with reference to the personalities involved in its development and its relationship with the South African Chemical Institute. The impact of online publishing on the format of the Journal and the ways in which the handling of submitted manuscripts have changed over time are discussed. Some statistics are presented illustrating the changing topicality of the various chemistry disciplines over time, as well as the expansion of the potential pool of authors arising from the internationalization of the scientific publishing field. Reference is also made to the quantitative measures by which the integrity and international acceptance of the Journal are judged.
\end{abstract}

KEYWORDS

History, personalities, online publishing, statistics.

\section{Introduction}

The South African Chemical Institute was established, as the South African Association of Analytical Chemists, in 1912. ${ }^{1-3}$ The first issue of any publication aspiring to be a national chemistry journal was that of the Journal of the South African Association of Analytical Chemists, which appeared in January 1918. The first page of the first issue is illustrated in Fig. 1a. The style of the type face is consistent with the age of the document - at that time the First World War still had eleven months to run. The Journal was published half-yearly and it was intended mainly to keep members who lived outside the Witwatersrand updated about the Association's activities, and contained only four technical papers. In January 1922, with the change of name of the organization the Journal also adopted a new name, and the first issue of Volume 5 of the Journal of the South African Chemical Institute appeared, following the numbering sequence initiated in 1918 (see Fig. 1b). Frequency of publication was also halfyearly until 1968, when it increased to three issues per year.

1977 saw the first appearance of the Journal under its present name, the South African Journal of Chemistry, and it moved to a quarterly publication schedule. Fig. 1c illustrates the first page of the new publication. Notable features were that papers could be submitted in either official language of the time and the requirement that abstracts should be submitted in both official languages. The numbers of papers published in Afrikaans remained small throughout the 1970s and 1980s, at a rate of about one paper every three years, most notably emanating from Potchefstroom University for Christian Higher Education. The last Afrikaans paper appeared in 1990. The reference to Kelvin House is a reminder that since 1937 the Institute had established its headquarters at Kelvin House, in the Johannes-

* To whom correspondence should be addressed. E-mail: ford@ukzn.ac.za burg CBD, along with sister organizations in the Association of Scientific and Technical Societies of SA, until the building was sold in 1990. It was here that the secretariat was located, and where the Institute's archival material was housed.

\section{Management}

The management of the production of the Journal was in the hands of a publications committee which oversaw, in addition to the Journal itself, a number of news and general chemical publications such as The South African Industrial Chemist, SA Chemical Processing, ChemSA and Chemical World, which flourished briefly. Although these publications provided a limited source of revenue through advertising, their publication was eventually discontinued. Table S1 of the Supplementary Material lists the names of the chairpersons of the publications committee, who were also known as the publications officers.

The responsibility for the content, the appointment of referees and the maintenance of the technical quality of the Journal rested with the editors-in-chief (coordinating editors), initially single-handedly and later, from about 1996, assisted by a team of subject editors for the traditional disciplines analytical, inorganic, organic and physical chemistry, and later also chemistry education. For a short time this ad hoc body also managed the editorial functions, the chairmanship of the group rotating annually among the subject editors, until in 2001 the responsibility for the functioning of the Journal once again reverted to a single coordinating editor. The editors-in-chief are listed in Table S2 of the Supplementary Material and some of them are pictured in Fig. S1. The longest-serving editor-in-chief was Professor James Bull, of the CSIR and later of the University of Cape Town, who enjoyed a tenure of some twenty years. He was known for his meticulous attention to detail, as exemplified by the following anecdote. The first paper of one of the present 


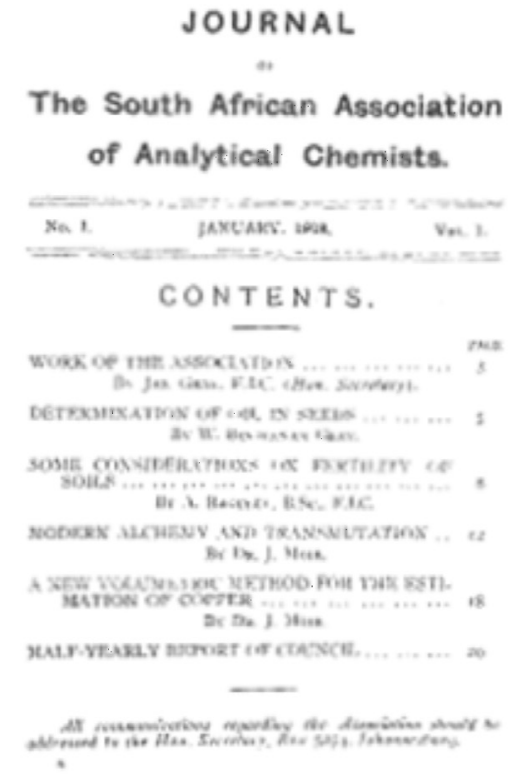

(a)

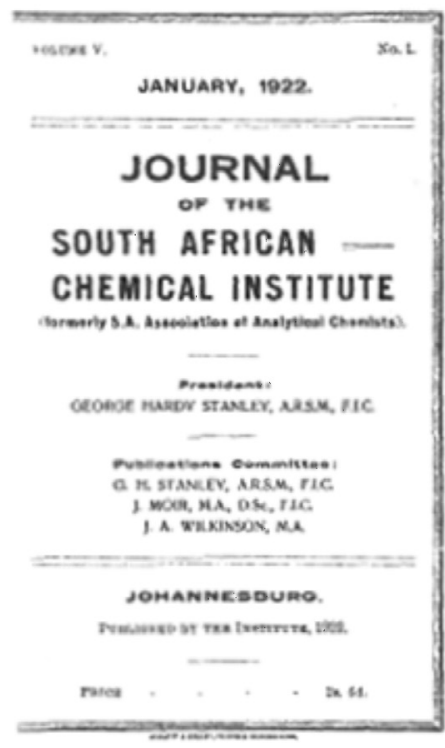

(b)

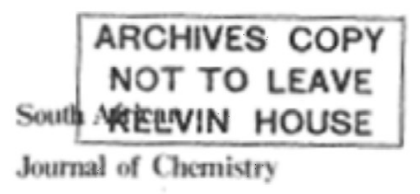

Suid-Afrikaanse

Tydskrif vir Chemic

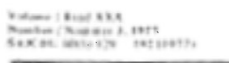

(c)

Figure 1 The first pages of (a) the Journal of the South African Association of Analytical Chemists, Volume 1, no. 1, January 1918, (b) the Journal of the South African Chemical Institute, Volume 5, no. 1, January 1922, (c) the South African Journal of Chemistry, Volume 30, no. 1, 1977.

authors published in the Journal had a Chilean co-author, Ricardo Aroca, and it was Spanish custom to include, along with a person's surname, the initial letter of his mother's maiden name, in this case Muñoz (see Fig. S2 in Supplementary Material). Puzzled by the unexpected $\mathrm{M}$ in the list of authors of the manuscript, and unwilling to agree to publishing something of a dubious nature, Professor Bull took the trouble to phone the author to ascertain the origin of the rogue letter M. Apparently satisfied by the explanation, he agreed to allow publication to go ahead.

With the large increase in the volume of submissions in recent years, the size of the editorial board has increased substantially, and as of July 2018 it now numbers 19 specialist editors covering not only the original subject areas but also the newer interdisciplinary branches such as materials science, nanotechnology and computational chemistry. Also as a result of the increase in the numbers of submissions, and in order to expand the pool of coordinating editors, since 2017 two editors-in-chief have taken charge on a two-year rotational basis. In the first year one editor deals with accepted papers until they are published, while the second editor handles the new incoming submissions until they are accepted. In the second year the two editors exchange roles.

An International Advisory Board was established in 2009, comprising a number of distinguished chemists who have had strong links with South Africa in one way or another. The members of the advisory board are listed in Table S3 of the Supplementary Material.

\section{Financial and Technical Support}

The costs of production of the Journal were initially largely borne by Institute members, through their normal annual subscriptions, but with some financial assistance from the government of the day through its various agencies. The sources of this support are described in Table S4. The support has also extended to the technical aspects of layout and typesetting, and the distribution of hard copies to members and to external subscribers such as libraries. Since the Journal went online, hard copies and CDs are no longer sold, hence that source of funding has been lost, and the Institute currently covers all the costs of producing the Journal.

\section{Special Issues}

In order to encourage submissions with a particular focus, a number of special issues were produced, commemorating notable events, or publishing papers presented at topical local conferences (see Table S5). This had the effect of increasing markedly the numbers of contributions in those themed issues.

\section{Covers}

For many years since 1977 the front cover of the Journal had a rather eye-catching appearance, with a dusky pink background, as illustrated in Fig. 2a. However, it became quite monotonous for members to receive their copies of this rather lurid document in their pigeon-holes four times a year. On the initiative of Dr Bruce Rae, the Institute president at the time, from issue 2 of 1997 pictorial covers were introduced. These included an illustration of the thermite reaction (courtesy of Professor Michael Laing of the University of KZN), the original AECI laboratory building at Modderfontein, and Professor Jan Albert van den Berg (Potchefstroom University for Christian Higher Education) on the occasion of his 80th birthday. He would have celebrated his own centenary in 2018. These covers are illustrated in Figs. 2b-2d.

\section{Prizes}

In 1961 AECI sponsored a gold medal and a cash prize, to be awarded to the senior author of the best paper published in the Journal in a specific field, rotating among papers representing the four traditional disciplines on a four-yearly cycle. On the demise of the R \& D function of AECI, the medal was placed in abeyance until 2000, when Merck took over the sponsorship of the award. Some of the notable winners of these two awards are presented in Table S6. These three colleagues were selected for mention since they have been multiple winners of one medal or the other. Taking the two medals together, Professor Jan Boeyens (CSIR and later Wits University) and Dr Eric Singleton (CSIR) have both been winners on three occasions, but at the top of the 


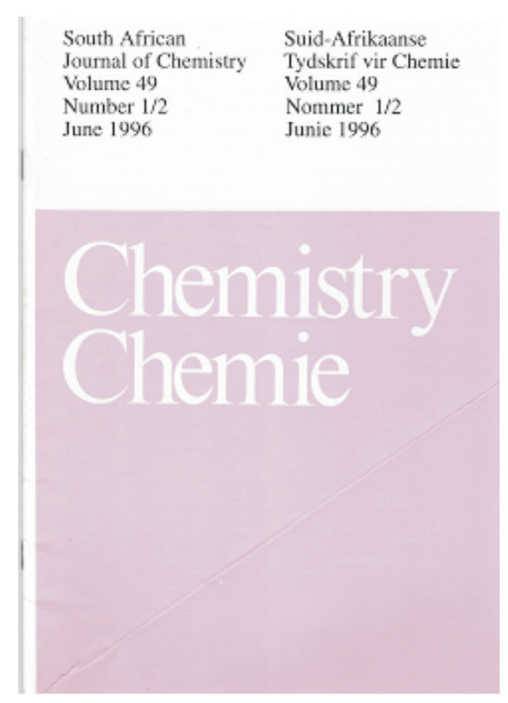

(a)

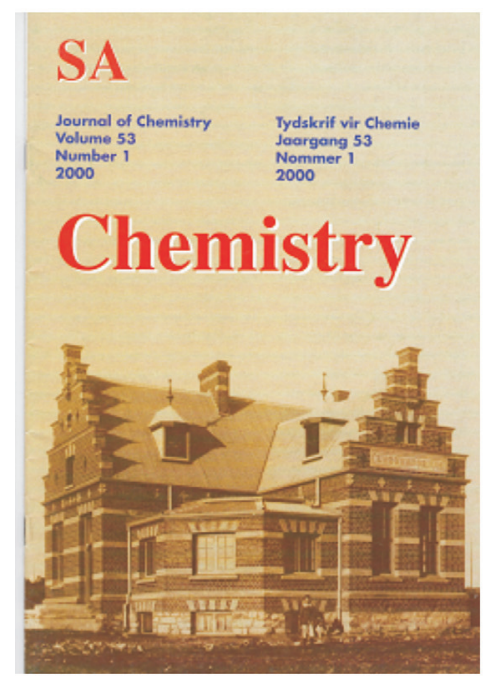

(c)

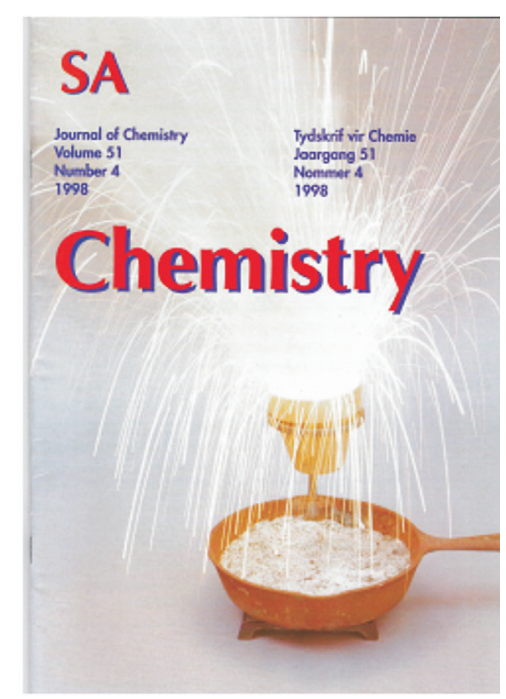

(b)

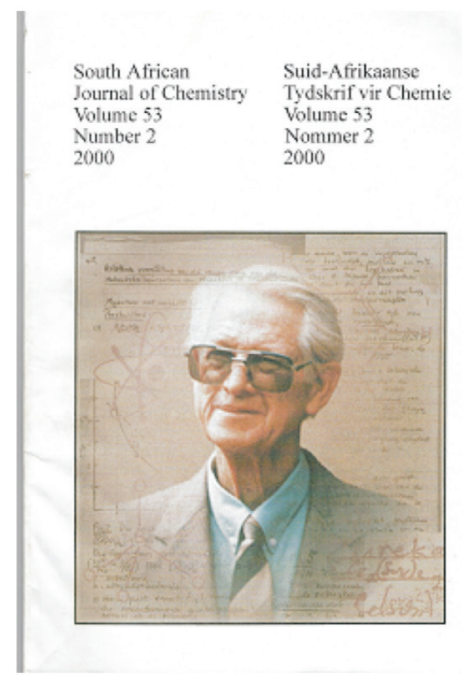

(d)

Figure 2 The front covers of the South African Journal of Chemistry, (a) Volume 49, nos. 1/2, 1996, (b) Volume 51, no. 4, 1998, (c) Volume 53, no. 1, 2000, (d) Volume 53, no. 2, 2000.

leader board is Professor Neil Coville (Wits), with four awards. His loyalty to the Journal is commendable. With the availability of accurate statistics relating to citation frequencies, the conditions for the award of the Merck medal have since been changed, and it is now awarded to the senior author of the paper receiving the greatest number of citations in the previous five years, irrespective of the discipline represented by the paper.

\section{Non-Research Articles}

In order to increase the appeal of the Journal it was decided that from 1996, up to $25 \%$ of published papers could be general or non-research articles. This decision sparked a vigorous debate among members, some of whom supported the appearance of more general articles of a chemical nature (some even going so far as to state that these were the only articles that they enjoyed reading). On the other side were the traditionalists who viewed the Journal as a national repository of serious academic research, and who were concerned that the integrity of the Journal as a genuine international research vehicle would be damaged by the inclusion of non-research material. Volumes 50 (issues 2 and 3, 1997), 51 (issues 1, 2 and 4, 1998) and 52 (issue 2, 1999) contained a total of eight non-research articles, mainly reporting on the current Nobel prize-winners in Chemistry, and general information reproduced from IUPAC. Issue 4 of volume 51 of 1998 caused some confusion at the Bureau for Scientific Publications, which was responsible for the layout and typesetting of the Journal, between non-research articles and short communications. The authors of some short communications which were classified erroneously in the Journal as non-research articles were justifiably aggrieved at this misrepresentation, not least since they realized that they would not be able to claim subsidy for such papers, since general articles were not subject to peer review. The publication of non-research articles was discontinued from 2000.

\section{Electronic Publishing}

In 2000 the Bureau for Scientific Publications indicated that it was no longer prepared to subsidize the continued production of the Journal, and the Institute was faced with the prospect of carrying the entire cost of publication, which was unsustainable. A debate then took place over whether the Journal should move to electronic publishing - the alternative being to cease publication altogether. Again, members were divided in their opinions, but by a small majority the decision was made to discontinue the 
print version with issue 2 of volume 53, and to publish all subsequent articles online as soon as they were finalized. The Professor van den Berg special issue was the last hard copy issue to be produced (see Fig. 2d).

Traditionally, authors would submit three hard copies of their articles to the secretariat, where Miss Efty Tsimas and later Mrs Lily Giacovazzi would log the submissions and forward the package to the coordinating editor, who would then send the individual copies to the selected referees. By 2003, however, most manuscripts were submitted by e-mail directly to the editor-in-chief. This system had obvious advantages as it avoided the labour of redirecting hard copy manuscripts from the secretariat through the editor-in-chief to the reviewers, thereby saving postage and photocopying charges and, in principle, shortening the time to publication. However, this system also had its disadvantages, as it made it too easy for unscrupulous authors to recycle manuscripts which had obviously been rejected by other journals with very little extra effort on their parts. As a result an early rejection system was introduced in 2005, which enabled the editor-in-chief to filter out those manuscripts which stood very little chance of passing successfully through the refereeing process, thereby saving the subject editors and their referees the embarrassment of having to deal with large numbers of sub-standard submissions.

In 2011 the Journal experienced its first case of fraud. A student, without the knowledge of his co-authors, submitted a paper which had already been published elsewhere, citing himself as the primary author. Fortunately the attempted fraud was uncovered and the paper was black-listed.

By 2012 throughput was streamlined still further by the introduction of an online submission system. This too had the disadvantage that, while it automated the processing of manuscripts, it still did not overcome the large volume of unsuitable submissions. As part of the present online submission process, potential articles are automatically subjected to scrutiny by TurnItIn; hopefully future attempts at plagiarism and other unethical practices will be detected at source.

In line with modern practice, the Journal has been open access since 2014, and is registered with the Directory of Open Access Journals. It is also registered with the Scientific Library Online (SciELO SA). The Journal is accredited by the Department of Higher Education and Training, and by the Arts and Humanities Citation Index (Web of Science Core Collection). Since its inception it has been abstracted by the usual abstracting services, including Chemical Abstracts, Current Web Contents and Web of Knowledge. It is one of only two African chemistry journals which are ISI-accredited, the other being the Bulletin of the Chemical Society of Ethiopia. All published papers dating right back to 1918 are now accessible electronically. ${ }^{4}$

\section{Statistics}

The numbers of papers published, year by year, have shown some fluctuations. The early 1990s, in particular, were subject to some noticeable variations in numbers of papers processed. As a result of problems at the Bureau, the publication schedules were severely disrupted, such that several times issues had to be combined; for seven years between 1990 and 1999 only two or three issues appeared per year, with fewer than 100 journal pages being produced in 1993 and 1996. This was a matter of great concern to the publications officer, Mr Percy Bloom, who expressed extreme dissatisfaction with the performance of the publishing house. A lack of confidence on the part of authors became apparent, mainly due to uncertainties as a result of the erratic appearance of the issues of the Journal, leading to a consequent decline in submissions. The numbers of papers published by year, from 1977 to 2000, and the number of journal pages, are illustrated graphically in Fig. 3, and are listed in detail in Table S7. Another significant slump occurred between 2001 and 2004. Once authors had become familiar with the use of the electronic publication system, however, numbers of submissions recovered again, and from 2006 the editor-in-chief was regularly receiving over 100 manuscripts per year, with a record 243 papers being submitted in 2014. From 2001, when the editors-in-chief started recording the numbers of submissions received per year in their annual reports, it was possible accurately to monitor the throughput of manuscripts. The numbers of manuscripts received and papers published, and numbers of journal pages per year from 2001 to 2018 are presented in graphical form in Fig. 4 and are shown in Table S8.

With increased numbers of submissions being received there was an inevitable rise in the number of rejected manuscripts. Rejection rates varied, but since 2002 these rates were consistently well above $50 \%$ (see Fig. 5 and Table S9). This is a testimony to the diligence of the subject editors and their judicious choices of conscientious referees.

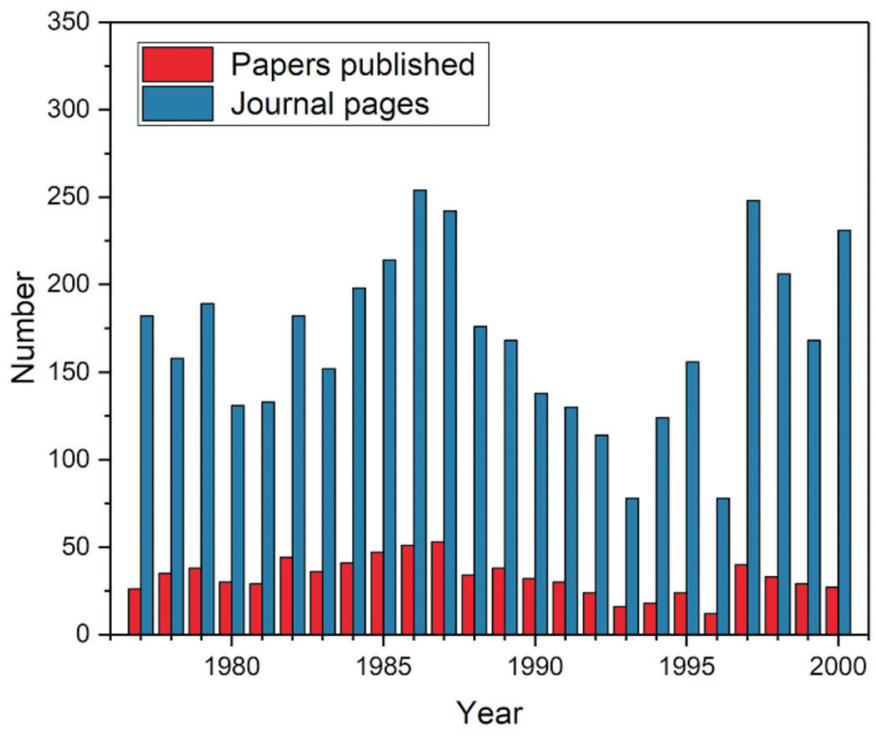

Figure 3 Numbers of papers published, and journal pages, 1977-2000.

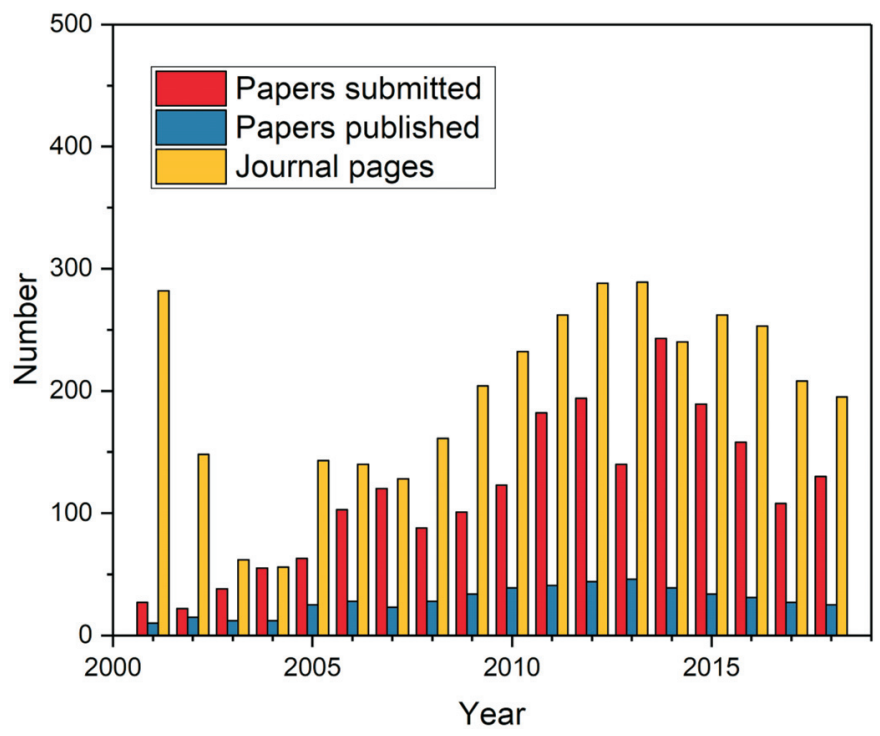

Figure 4 Numbers of papers submitted and published, and journal pages, 2001-2018. 


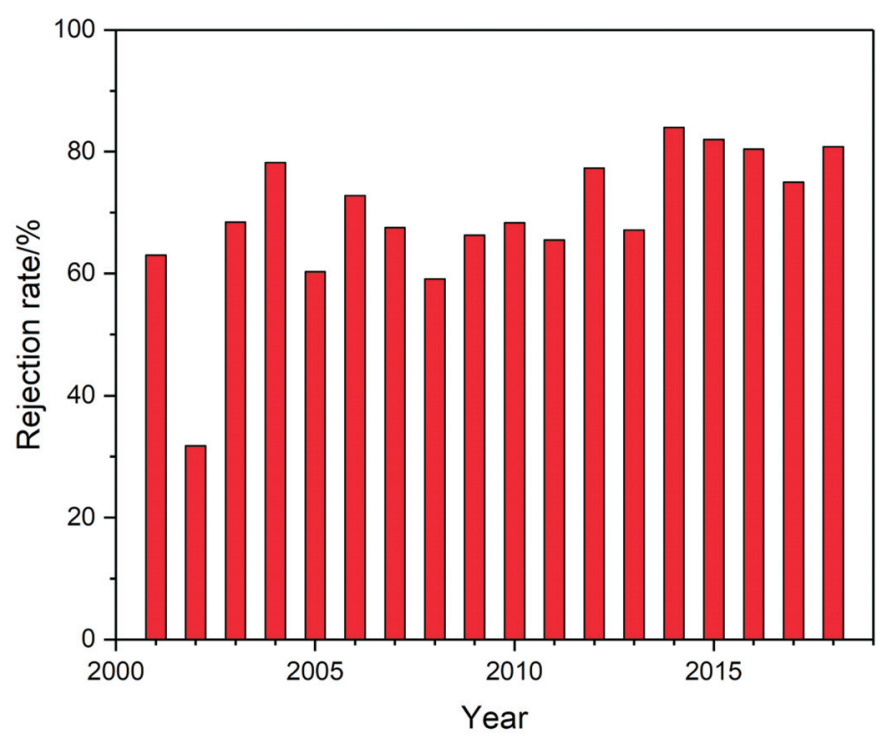

Figure 5 Rejection rates, 2001-2018.

From 2000, when the Journal started routinely including the dates of submission, revision and acceptance for each paper published, it became easy to record the rates of progress of manuscripts through the publication system. Associated with the streamlining of the publication process, the average times from submission to publication saw a steady reduction and the fastest times to publication indicated some fairly rapid turnovers from 2010 to 2016. These times to publication are reported in Fig. 6 and Table S10. The record for the shortest delay from submission to appearance online, one which may never be broken, was achieved in 2011. This record was enjoyed by a paper reviewing 20 years of research and development of battery technology at the CSIR from 1974 to 1994. It was submitted in response to an invitation by the editor-in-chief to Institute members to celebrate the International Year of Chemistry in 2011. It was accepted 10 days after it was received. At the other end of the scale no fewer than 48 publications have had gestation periods in excess of one year. Most of these submissions were from foreign authors, and the long delays can be largely attributed to the need for successive revisions to be carried out in order to improve the quality of the English. The longest period between submission and publication, 1086 days, was experienced by a

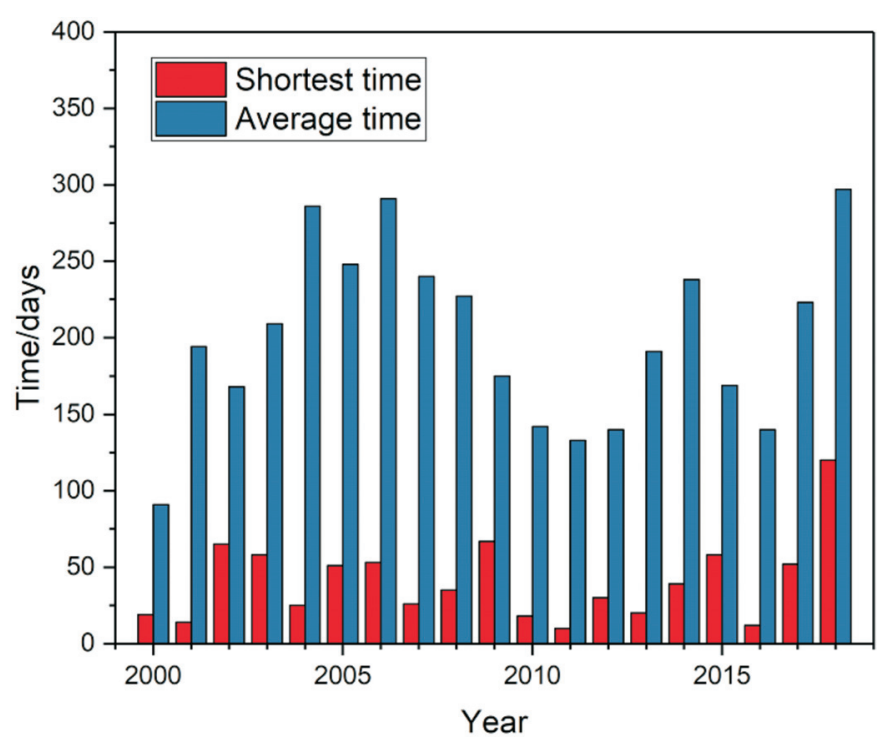

Figure 6 Shortest and average times to publication, 2000-2018. paper on chemistry education, the revision of which took over two years before the manuscript was resubmitted. The editors are well aware of the need to put pressure on their more tardy reviewers, and to encourage authors to complete the required revisions with the minimum of delay, the alternative being for the editors summarily to withdraw the manuscripts from the publication stream.

One of the measures of the international standing of a scientific publication is its impact factor. Since 1983, accurate statistics relating to annual impact factors have become available. With a few exceptions these numbers have varied in a band between 0.3 and 0.5 , but since 2014 they have regularly exceeded 0.6 and the latest figure available, that for 2017, is close to 1.0 (see Fig. 7 and Table S11).

As a non-specialist periodical, the Journal has always accepted papers from all branches of chemistry. While the popularity of the four traditional disciplines has been subject to unpredictable fluctuations, over the period from 1977 to 2018 analytical, inorganic and particularly organic chemistry have been consistently the most strongly represented areas. In the case of organic chemistry, the popularity of this field among local authors can be attributed chiefly to the long-standing tradition of research in natural product chemistry in South Africa. In recent years, however, papers in catalysis, computational chemistry, green chemistry, materials science and nanochemistry, for example, have reflected international trends in the upsurge of interest in those newer branches of chemistry. These branches are grouped together as 'other' in Fig. 8 and Table S12. Chemistry education has been consistently under-represented over many years.

In its early years, apart from the odd submission mainly from the UK, USA, Germany and India, the Journal published papers exclusively from South African authors. Due mainly to the new political dispensation, the position changed in 1994, with the start of an influx of papers from other countries, notably from elsewhere in Africa. In that year for the first time the percentage of South African manuscripts fell below $80 \%$ of the total and in 2007 the percentage reached its lowest level of $30 \%$. Since then, the percentage of South African papers published has exceeded $50 \%$ only in 2009, 2011 and 2016. A breakdown of published papers according to countries of origin is given in Fig. 9 and Table S13. These data show the spread of regions of the world from which potential authors have found the Journal to be an agreeable vehicle in which to showcase their work. In the period

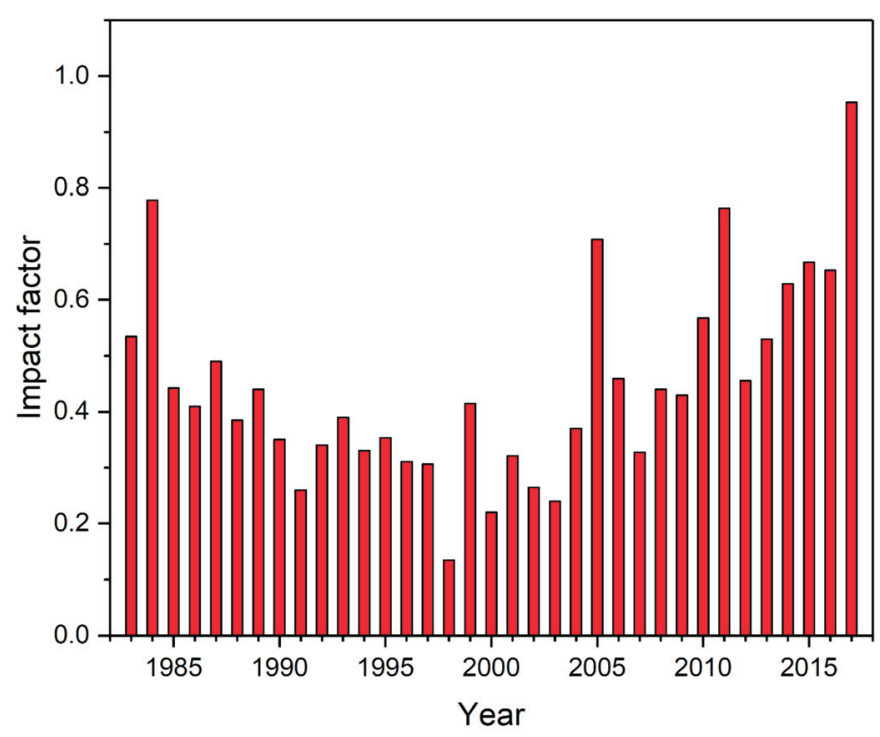

Figure 7 Impact factors, 1983-2017. 


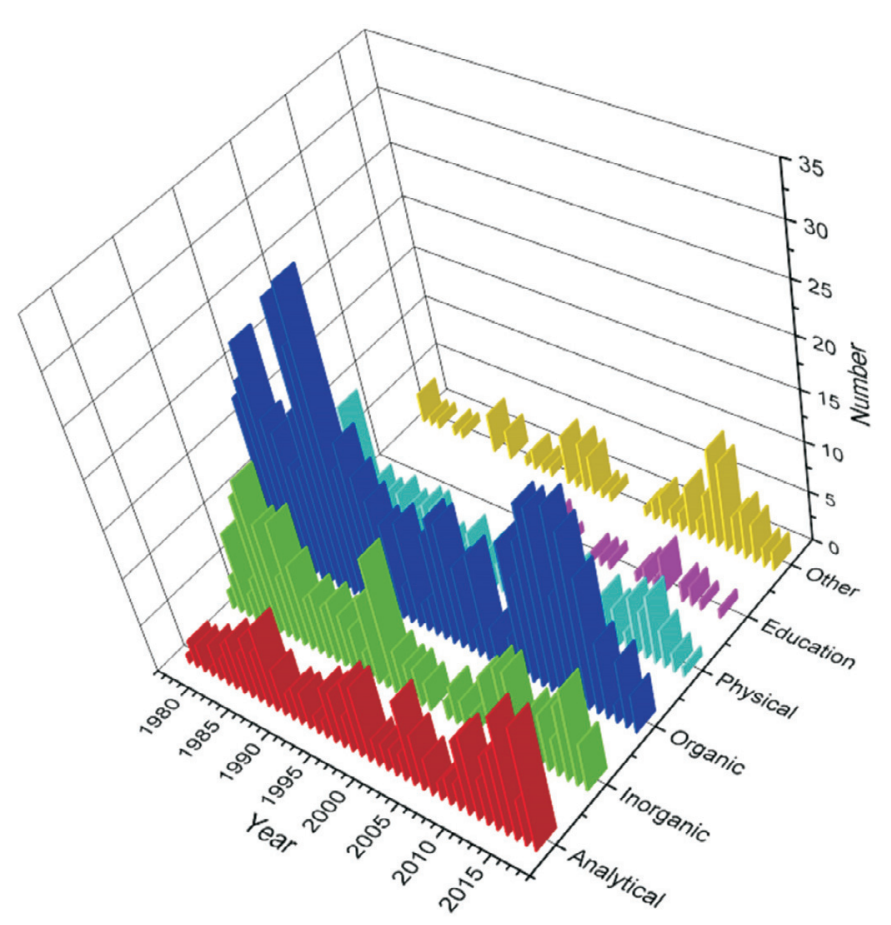

Figure 8 Breakdown of numbers of papers published by discipline, 19772018.

from 2000 to 2018 the leading countries from which foreign manuscripts originated have been Iran, India and China, while a small number have been received from such exotic locations as Oman, Guyana, Yemen and Macedonia.

The South African Journal of Chemistry continues to provide an avenue for the publication of quality work in all fields of chemistry, not only for local researchers, but increasingly for those from other countries, giving the Journal a truly international profile. The dedication of the editorial team in maintaining the high standards expected of a national flagship publication is to be commended, and it is hoped that future editors-in-chief and subject editors will continue to preserve this legacy. Provided the funding model of the Journal is maintained through the Institute, there is no reason why it cannot look forward to a further 100 years of successful promotion of internationally competitive chemistry research.

\section{Supplementary Material}

Supplementary information is provided in the online supplement.

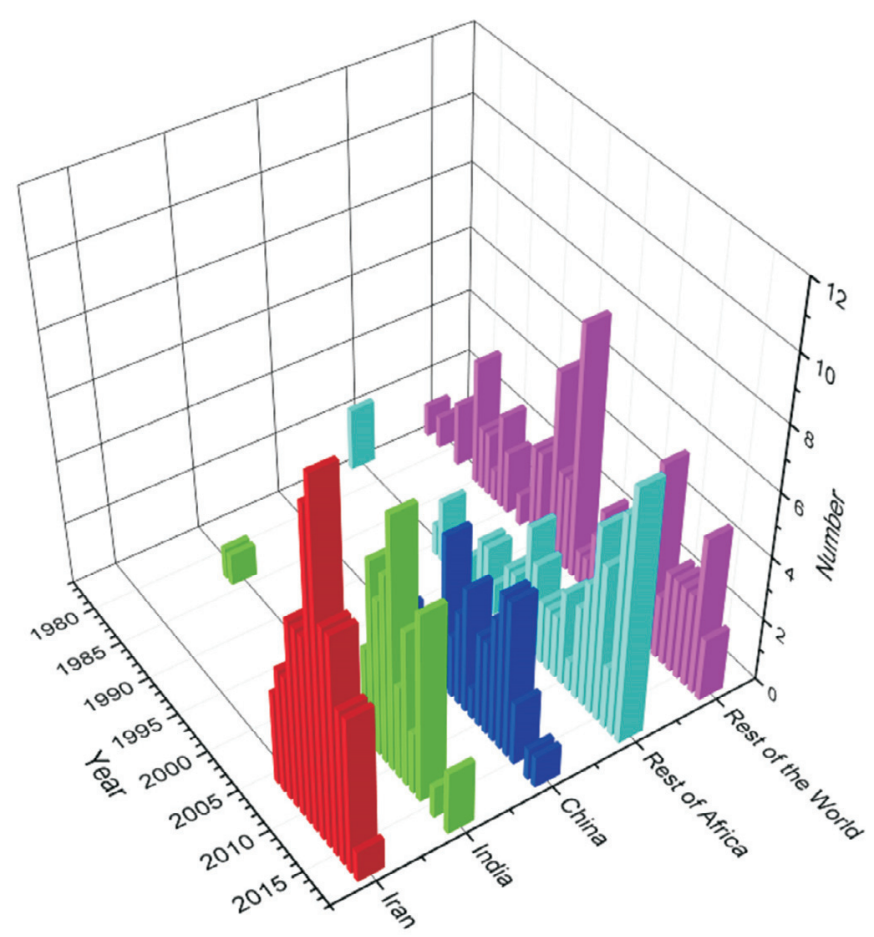

Figure 9 Breakdown of numbers of papers published by country of origin, 1977-2018.

\section{Acknowledgements}

The authors have relied heavily for material for this paper on the two official histories of the Institute, by Mr Douglas Gray (1987) and Professor Ivan Green (2012). Mrs Laila Smith, of the Institute secretariat, has also generously made available the Institute's annual reports and other valuable documents relating to the history of the Journal. The authors thank them most sincerely.

\section{SORCID iDs}

T.A. Ford:

H.G. Kruger:

(iD) orcid.org/0000-0002-8896-794X

P. Loyson: orcid.org/0000-0003-0606-2053 orcid.org/0000-0003-5487-2037

\section{References}

1. K. Mathieson. Fifty golden years. A history of the South African Chemical Institute, 1912-1962. S. Afr. Ind. Chemist, 1963, 17, 2-29.

2. D.J.S. Gray. The South African Chemical Institute 1912-1987. The South African Chemical Institute, Johannesburg, 1987, $25 \mathrm{pp}$.

3. I.R. Green. The South African Chemical Institute 1987-2012. The South African Chemical Institute, Johannesburg, 2012, 31 pp.

4. https://journals.co.za/content/journal/chem 


\section{Supplementary material to:}

T.A. Ford, H.G. Kruger and P. Loyson,

The South African Journal of Chemistry 1918-2018: A Celebration,

S. Afr. J. Chem., 2019, 72, 201-206. 
Supplementary Information, South African Journal of Chemistry

The South African Journal of Chemistry 1918 - 2018: A Celebration.

T. Anthony Ford, Hendrik G. Kruger and Peter Loyson

Table of Contents

Figure S1. Some of the editors-in-chief and coordinating editors of the South African Journal of Chemistry.

Figure S2. Extract from the paper S. Afr. J. Chem., 30, 95 -104 (1977).

Table S1. Publications committee chairpersons and publications officers.

Table S2. Editors-in-chief and coordinating editors.

Table S3. International advisory board.

Table S4. Financial and technical support.

Table S5. Special issues.

Table S6. AECl and Merck Medal winners.

Table S7. Numbers of papers published, and journal pages, $1977-2000$.

Table S8. Numbers of papers submitted and published, and journal pages, $2001-2018$.

Table S9. Rejection rates, 2001 - 2018.

Table S10. Times to publication, $2000-2018$.

Table S11. Impact factors, 1983 - 2018.

Table S12. Breakdown of numbers of papers published by discipline, $1977-2018$.

Table S13. Breakdown of numbers of papers published by country of origin, $1977-2018$. 


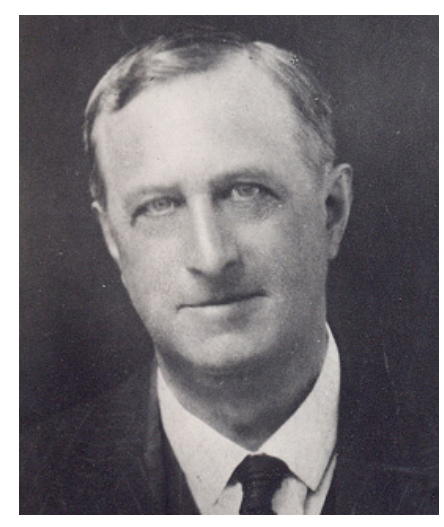

J. A. Wilkinson

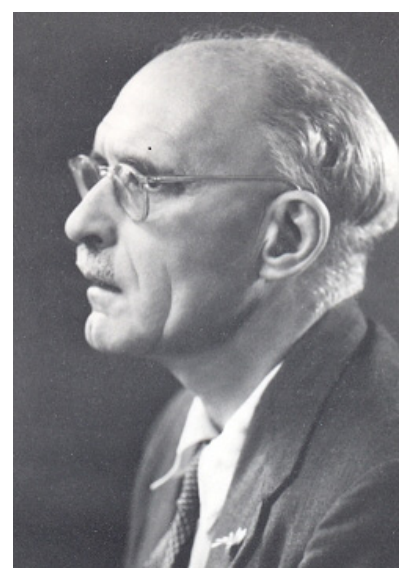

F. W. Fox

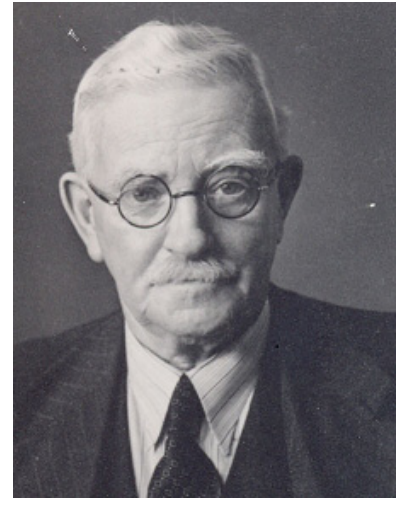

G. H. Stanley

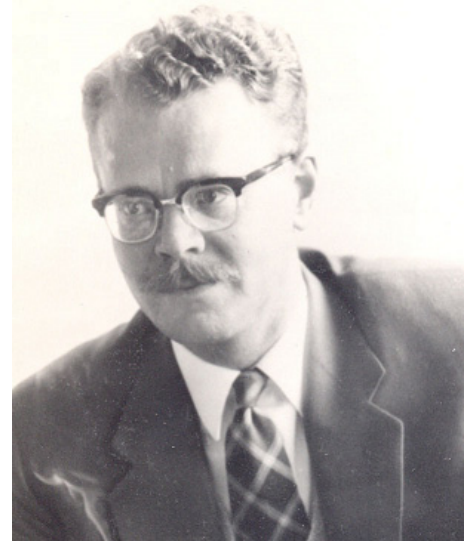

H. A. E. Mackenzie

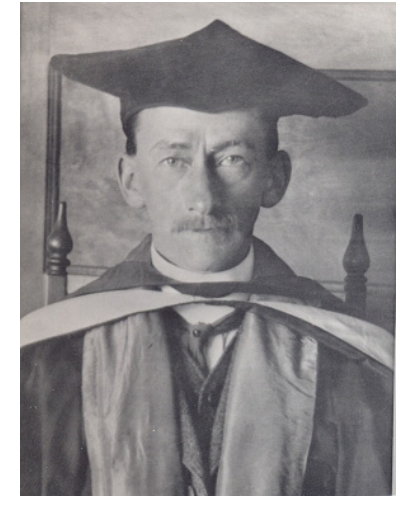

J. Moir

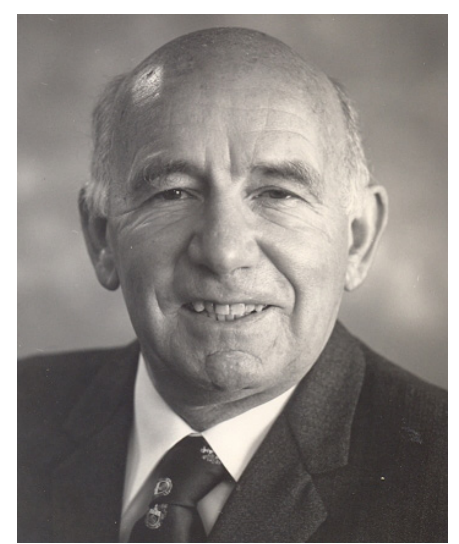

D. E. A. Rivett

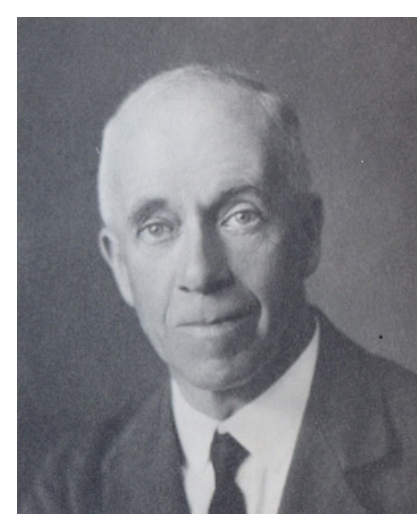

J. McCrae

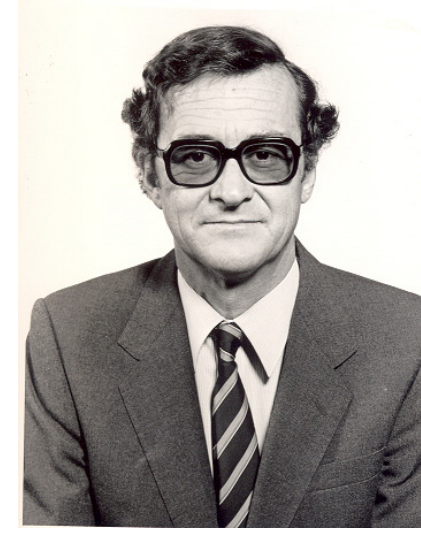

J. R. Bull

Figure S1. Some of the editors-in-chief and coordinating editors of the South African Journal of Chemistry. 


\title{
MOLECULAR VIBRATIONAL CONSTANTS OF SOME SIMPLE POLYATOMIC MOLECULES. DIHALOGENOMETHANES
}

\author{
T.A. FORD* \\ Department of Chemistry, University of the Witwatersrand, \\ Johannesburg 2001
}

R. AROCA M. and E.A. ROBINSON

Erindale College, University of Toronto,

Mississauga, Ontario, L5L 1C6, Canada

\begin{abstract}
Opsomming Die kragkonstantes en meegaande konstantes van die dihalogeenmetane is bereken deur die iteratiewe konsistensic-metode. Deur die kragvelde te gebruik wat sodoende verkry is, is die sentrifugale distorsiekonstantes, Coriolis-koppelingskonstantes en gemiddelde vibrasieamplitudes bereken en vergelyk met die beskikbare eksperimentele gegewens.

Summary The force constants and compliance constants of the dihalogenomethanes have been calculated by the iterative consistency method. The force fields so obtained were used to calculate the centrifugal distortion constants, Coriolis coupling constants and mean amplitudes of vibration which were compared with the available experimental data.
\end{abstract}

Figure S2. Extract from the paper S. Afr. J. Chem., 30, 95-104 (1977). 
Table S1. Publications committee chairpersons and publications officers.

$\begin{array}{llll}\text { J. A. Wilkinson } & 1918-1924 & \text { S. Goodman } & 1961-1965 \\ \text { J. Moir } & 1925 & \text { R. E. Robinson } & 1966 \\ \text { C. C. Frye } & 1926-1929 & \text { S. Goodman } & 1967-1974 \\ \text { O. L. Ochse } & 1930-1932 & \text { R. R. Arndt } & 1975-1977 \\ \text { J. A. McLachlan } & 1933-1939 & \text { F. E. Malherbe } & 1977-1983 \\ \text { B. Segal } & 1940 & \text { J. R. Bull } & 1983-1984 \\ \text { S. S. Israelstam } & 1941-1947 & \text { C. J. H. Schutte } & 1984-1989 \\ \text { H. Stephen } & 1948 & \text { P. Bloom } & 1989-1999 \\ \text { A. W. Lategan } & 1949-1952 & \text { W. H. Meyer } & 2000-2006\end{array}$

S. S. Israelstam $1953-1960$ 
Table S2. Editors-in-chief and coordinating editors.

$\begin{array}{llll}\text { J. A. Wilkinson } & 1918-1921 & \text { D. E. A. Rivett } & 1958-1966 \\ \text { G. H. Stanley } & 1922-1923 & \text { O. G. Backeberg } & 1966-1971 \\ \text { J. Moir } & 1924-1927 & \text { J. R Bull } & 1972-1992 \\ \text { J. McCrae } & 1928 & \text { A. T. Hutton } & 1993-1996 \\ \text { F. W. Fox } & 1929-1939 & \text { (ad hoc) } & 1997-2000 \\ \text { H. D. Barnes } & 1940-1947 & \text { W. H. Meyer } & 2001-2007 \\ \text { H. Stephen } & 1947-1948 & \text { T. A. Ford } & 2007-2010 \\ \text { K. A. Murray } & 1948-1952 & \text { G. E. Jackson } & 2010-2014 \\ \text { H. A. E. Mackenzie } & 1953-1955 & \text { H. G. Kruger } & 2014-2017 \\ \text { L. J. Dry } & 1956-1957 & \text { L. Chimuka and T. Naicker } & 2017-2018\end{array}$


Table S3. International advisory board.

E. Alessio
A. J. Barnes
R. Bucat
U. Domanska-Zelazna
H. G. M. Edwards
I. Fleming
L. Glasser
G. J. Hutchings
T. M. Letcher
R. Simoyi
C. J. van der Schyff
R. van Eldik
R. M. A. von Wandruska

Trieste

Salford

Perth

Warsaw

Bradford

Cambridge

Perth

Cardiff

Bath

Portland, OR

Rootstown, $\mathrm{OH}$

Erlangen-Nürnberg

Moscow, ID
Italy

U.K.

Australia

Poland

U.K.

U.K.

Australia

U.K.

U.K.

U.S.A.

U.S.A.

Germany

U.S.A. 
Table S4. Financial and technical support.

FINANCIAL

Department of Education, Arts and Sciences

(later the Department of Cultural Affairs)

(later the Department of National Education)

SA Chemical Foundation (1972-1975)

Bureau for Scientific Publications of the Foundation for

Education, Science and Technology (1977-2000)

(became SA Scientific Publications 1995)

\section{TECHNICAL}

Sabinet (hosting of on-line publishing) (2000 to date)

Isteg Scientific Publications (technical editing and layout) (2002 to date) 
Table S5. Special issues.

\begin{tabular}{|c|c|c|c|}
\hline Year & Volume & Issue & Celebration \\
\hline 1970 & 23 & 2 & $\begin{array}{l}\text { Papers presented at the IUPAC International Symposium on the Chemical Control of the Human Environment, } \\
\text { Johannesburg, 14-18 July } 1969\end{array}$ \\
\hline 1972 & 25 & 3 & $\begin{array}{l}\text { Papers presented at the Symposium on the Analytical Chemistry of the Platinum Group Metals, Johannesburg, 2-4 } \\
\text { February } 1972\end{array}$ \\
\hline 1982 & 35 & 4 & Diamond Jubilee of the University of the Witwatersrand \\
\hline 1984 & 37 & 3 & $50^{\text {th }}$ Anniversary of the Council for Mineral Technology \\
\hline 1985 & 38 & 3 & $75^{\text {th }}$ Anniversary of the University of Natal \\
\hline 1986 & 39 & 3 & $\begin{array}{l}\text { Papers presented at the } 2^{\text {nd }} \text { International Symposium on Analytical Chemistry in the Exploration, Mining and } \\
\text { Processing of Minerals, Pretoria, } 15-19 \text { April } 1985\end{array}$ \\
\hline 1986 & 39 & 4 & $90^{\text {th }}$ Birthday of Professor O. G. Backeberg (University of the Witwatersrand) \\
\hline 1987 & 40 & 1 & Retirement of Professor D. E. A. Rivett (Rhodes University) \\
\hline 1994 & 47 & $3 / 4$ & Papers presented at the $32^{\text {nd }} \mathrm{SACI}$ Convention, Halfway House, 30 January -3 February 1994 \\
\hline 1995 & 48 & $1 / 2$ & \\
\hline 1995 & 48 & $3 / 4$ & \\
\hline 1997 & 50 & 4 & $\begin{array}{l}\text { Papers presented at the } 4^{\text {th }} \text { International Symposium on Applied Bioinorganic Chemistry, incorporating the Carman } \\
\text { National Physical Chemistry Symposium, Cape Town, 1-4 April } 1997\end{array}$ \\
\hline 2000 & 53 & 2 & $80^{\text {th }}$ Birthday of Professor J. A. van den Berg (Potchefstroom University for Christian Higher Education) \\
\hline
\end{tabular}


Table S6. AECI and Merck Medal winners.

AECI Medal, $1961-1998$

Jan Boeyens (CSIR and Wits University)

1973,1980

Eric Singleton (CSIR)

$1981,1986,1990$

Neil Coville (Wits University)

1994

Merck Medal, 2000 to date

Neil Coville (Wits University)

$2002,2010,2015$

Jan Boeyens (Wits University)

2003 
Table S7. Numbers of papers published, and journal pages, 1977 - 2000.

\begin{tabular}{|c|c|c|c|c|c|c|c|c|}
\hline Year & $\begin{array}{c}\text { Number of } \\
\text { papers } \\
\text { published }\end{array}$ & $\begin{array}{c}\text { Number of } \\
\text { journal } \\
\text { pages }\end{array}$ & Year & $\begin{array}{c}\text { Number of } \\
\text { papers } \\
\text { published }\end{array}$ & $\begin{array}{c}\text { Number of } \\
\text { journal } \\
\text { pages }\end{array}$ & Year & $\begin{array}{c}\text { Number of } \\
\text { papers } \\
\text { published }\end{array}$ & $\begin{array}{c}\text { Number of } \\
\text { journal } \\
\text { pages }\end{array}$ \\
\hline 1977 & 26 & 182 & 1985 & 47 & 214 & 1993 & 16 & 18 \\
\hline 1978 & 35 & 158 & 1986 & 51 & 254 & 1994 & 124 \\
\hline 1979 & 38 & 189 & 1987 & 53 & 242 & 1995 & 124 & 78 \\
\hline 1980 & 30 & 131 & 1988 & 34 & 176 & 1996 & 12 & 40 \\
\hline 1981 & 29 & 133 & 1989 & 38 & 168 & 1997 & 248 \\
\hline 1982 & 44 & 182 & 1990 & 32 & 138 & 1998 & 33 & 206 \\
\hline 1983 & 36 & 152 & 1991 & 30 & 130 & 1999 & 29 & 168 \\
\hline 1984 & 41 & 198 & 1992 & 24 & 114 & 2000 & 27 & 231 \\
\hline
\end{tabular}


Table S8. Numbers of papers submitted and published, and journal pages, 2001 - 2018.

\begin{tabular}{|c|c|c|c|c|c|c|c|}
\hline Year & $\begin{array}{c}\text { Number } \\
\text { of papers } \\
\text { submitted }\end{array}$ & $\begin{array}{c}\text { Number } \\
\text { of papers } \\
\text { published }\end{array}$ & $\begin{array}{c}\text { Number } \\
\text { of journal } \\
\text { pages }\end{array}$ & Year & $\begin{array}{c}\text { Number } \\
\text { of papers } \\
\text { submitted }\end{array}$ & $\begin{array}{c}\text { Number } \\
\text { of papers } \\
\text { published }\end{array}$ & $\begin{array}{c}\text { Number } \\
\text { of journal } \\
\text { pages }\end{array}$ \\
\hline 2001 & 27 & 10 & 282 & 2010 & 123 & 39 & 232 \\
\hline 2002 & 22 & 15 & 148 & 2011 & 182 & 41 & 262 \\
\hline 2003 & 38 & 12 & 62 & 2012 & 194 & 44 & 288 \\
\hline 2004 & 55 & 12 & 56 & 2013 & 140 & 46 & 289 \\
\hline 2005 & 63 & 25 & 143 & 2014 & 243 & 39 & 240 \\
\hline 2006 & 103 & 28 & 140 & 2015 & 189 & 34 & 262 \\
\hline 2007 & 120 & 23 & 128 & 2016 & 158 & 31 & 253 \\
\hline 2008 & 88 & 28 & 161 & 2017 & 108 & 27 & 208 \\
\hline 2009 & 101 & 34 & 204 & 2018 & 130 & 25 & 195 \\
\hline
\end{tabular}


Table S9. Rejection rates, 2001 - 2018.

\begin{tabular}{|c|c|c|c|c|c|}
\hline Year & $\begin{array}{c}\text { Rejection } \\
\text { rate/\% }\end{array}$ & Year & $\begin{array}{c}\text { Rejection } \\
\text { rate/\% }\end{array}$ & Year & $\begin{array}{c}\text { Rejection } \\
\text { rate/\% }\end{array}$ \\
\hline 2001 & 63.0 & 2007 & 67.5 & 2013 & 67.1 \\
\hline 2002 & 31.8 & 2008 & 59.1 & 2014 & 84.0 \\
\hline 2003 & 68.4 & 2009 & 66.3 & 2015 & 82.0 \\
\hline 2004 & 78.2 & 2010 & 68.3 & 2016 & 80.4 \\
\hline 2005 & 60.3 & 2011 & 65.5 & 2017 & 75.0 \\
\hline 2006 & 72.8 & 2012 & 77.3 & 2018 & 80.8 \\
\hline
\end{tabular}


Table S10. Times to publication, 2000 - 2018.

\begin{tabular}{|c|c|c|c|c|c|c|c|}
\hline \multirow{2}{*}{ Year } & \multicolumn{3}{|c|}{ Time/days } & \multirow{2}{*}{ Year } & \multicolumn{3}{c|}{ Time/days } \\
\cline { 2 - 7 } & Shortest & Longest & Average & & Shortest & Longest & Average \\
\hline 2000 & 19 & 241 & 91 & 2010 & 18 & 621 & 142 \\
\hline 2001 & 14 & 410 & 194 & 2011 & 10 & 388 & 133 \\
\hline 2002 & 65 & 430 & 168 & 2012 & 30 & 330 & 140 \\
\hline 2003 & 58 & 386 & 209 & 2013 & 20 & 345 & 191 \\
\hline 2004 & 25 & 1086 & 286 & 2014 & 39 & 591 & 238 \\
\hline 2005 & 51 & 470 & 248 & 2015 & 58 & 398 & 169 \\
\hline 2006 & 53 & 742 & 291 & 2016 & 12 & 363 & 140 \\
\hline 2007 & 26 & 731 & 240 & 2017 & 52 & 572 & 223 \\
\hline 2008 & 35 & 543 & 227 & 2018 & 120 & 622 & 297 \\
\hline 2009 & 67 & 491 & 175 & & & & \\
\hline
\end{tabular}


Table S11. Impact factors, $1983-2018$.

\begin{tabular}{|c|c|c|c|c|c|}
\hline Year & Impact factor & Year & Impact factor & Year & Impact factor \\
\hline 1983 & 0.534 & 1995 & 0.353 & 2007 & 0.327 \\
\hline 1984 & 0.778 & 1996 & 0.310 & 2008 & 0.44 \\
\hline 1985 & 0.442 & 1997 & 0.306 & 2009 & 0.429 \\
\hline 1986 & 0.409 & 1998 & 0.135 & 2010 & 0.567 \\
\hline 1987 & 0.49 & 1999 & 0.414 & 2011 & 0.764 \\
\hline 1988 & 0.385 & 2000 & 0.22 & 2012 & 0.455 \\
\hline 1989 & 0.44 & 2001 & 0.321 & 2013 & 0.53 \\
\hline 1990 & 0.35 & 2002 & 0.265 & 2014 & 0.629 \\
\hline 1991 & 0.26 & 2003 & 0.24 & 2015 & 0.667 \\
\hline 1992 & 0.34 & 2004 & 0.37 & 2016 & 0.653 \\
\hline 1993 & 0.39 & 2005 & 0.708 & 2017 & 0.953 \\
\hline 1994 & 0.33 & 2006 & 0.459 & 2018 & $-a$ \\
\hline
\end{tabular}

${ }^{a}$ Not yet available. 
Table S12. Breakdown of numbers of papers published by discipline, 1977 - 2018.

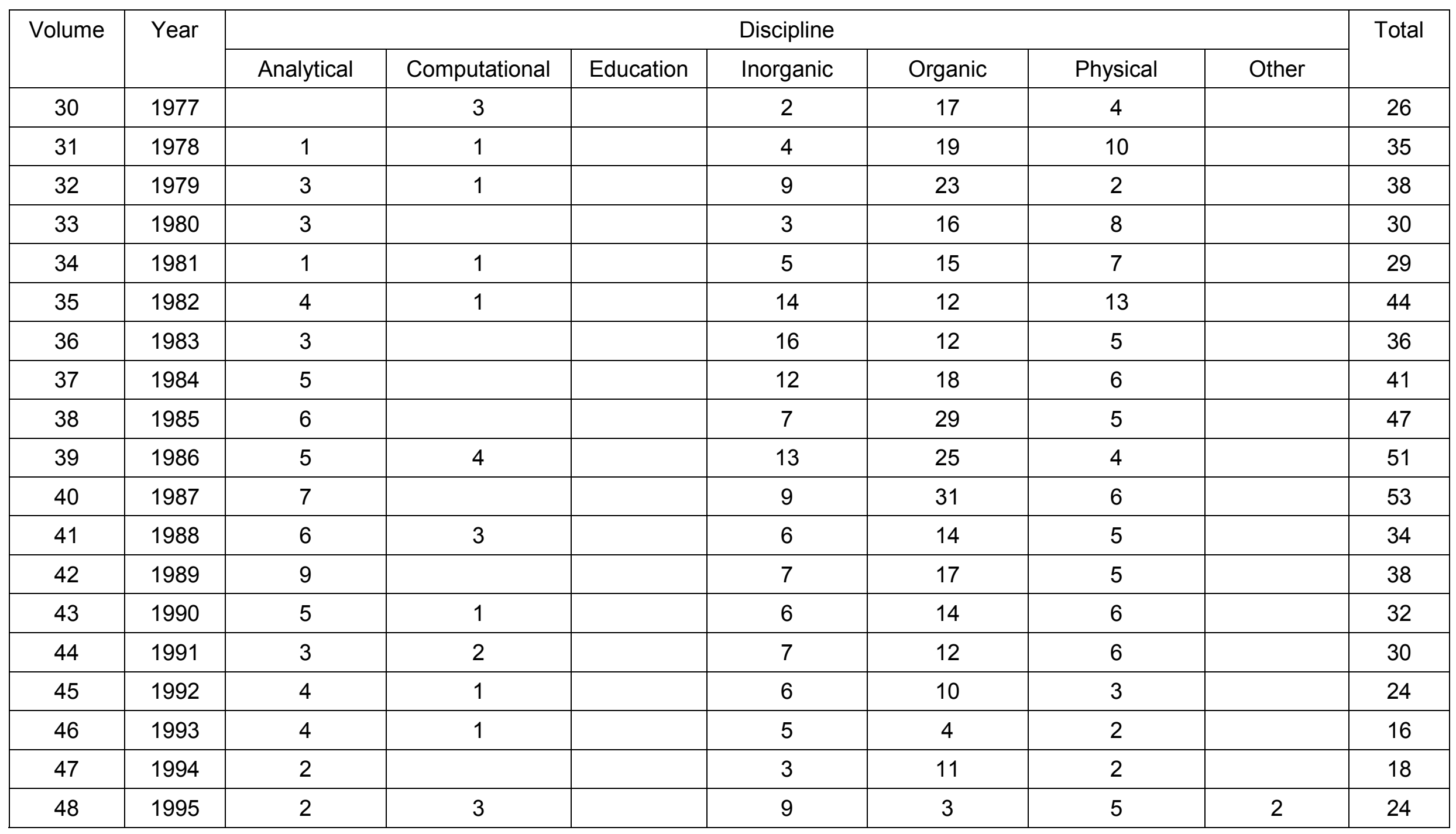




\begin{tabular}{|c|c|c|c|c|c|c|c|c|c|}
\hline 49 & 1996 & 6 & 1 & & 1 & 4 & & & 12 \\
\hline 50 & 1997 & 6 & 2 & & 14 & 11 & 4 & 3 & 40 \\
\hline 51 & 1998 & 4 & & 4 & 5 & 13 & 3 & 4 & 33 \\
\hline 52 & 1999 & 8 & & 3 & 4 & 13 & & 1 & 29 \\
\hline 53 & 2000 & 8 & 1 & 1 & 4 & 9 & 4 & & 27 \\
\hline 54 & 2001 & 3 & & & 3 & 3 & 1 & & 10 \\
\hline 55 & 2002 & 3 & & & & 11 & 1 & & 15 \\
\hline 56 & 2003 & 3 & & 1 & 2 & 4 & 2 & & 12 \\
\hline 57 & 2004 & 3 & & 1 & 4 & 1 & 2 & 1 & 12 \\
\hline 58 & 2005 & 9 & 1 & 1 & 3 & 4 & 6 & 1 & 25 \\
\hline 59 & 2006 & 6 & 3 & & 2 & 14 & 3 & & 28 \\
\hline 60 & 2007 & 4 & & & & 11 & 6 & 2 & 23 \\
\hline 61 & 2008 & 2 & 2 & 1 & 7 & 15 & 1 & & 28 \\
\hline 62 & 2009 & 3 & 3 & 2 & 4 & 19 & 1 & 2 & 34 \\
\hline 63 & 2010 & 3 & 1 & 1 & 9 & 19 & 5 & 1 & 39 \\
\hline 64 & 2011 & 8 & 1 & 4 & 9 & 11 & 4 & 4 & 41 \\
\hline 65 & 2012 & 9 & 2 & & 3 & 20 & 2 & 8 & 44 \\
\hline 66 & 2013 & 5 & 4 & 2 & 6 & 18 & 6 & 5 & 46 \\
\hline 67 & 2014 & 8 & & 2 & 6 & 14 & 5 & 4 & 39 \\
\hline 68 & 2015 & 9 & 1 & 1 & 4 & 8 & 7 & 4 & 34 \\
\hline 69 & 2016 & 13 & & & 8 & 2 & 4 & 4 & 31 \\
\hline 70 & 2017 & 5 & 1 & 1 & 10 & 7 & 2 & 1 & 27 \\
\hline 71 & 2018 & 13 & 1 & & 5 & 4 & 1 & 1 & 25 \\
\hline
\end{tabular}


Table S13. Breakdown of numbers of papers published by country of origin, $1977-2018$.

\begin{tabular}{|c|c|c|c|c|c|}
\hline \multirow[t]{2}{*}{ Volume } & \multirow[t]{2}{*}{ Year } & \multicolumn{2}{|r|}{ Country of origin } & \multirow{2}{*}{$\begin{array}{c}\text { Total } \\
\text { number } \\
\text { of papers } \\
\text { published }\end{array}$} & \multirow{2}{*}{$\begin{array}{c}\text { Percentage } \\
\text { South } \\
\text { African }\end{array}$} \\
\hline & & $\begin{array}{l}\text { South } \\
\text { Africa }\end{array}$ & Other & & \\
\hline 30 & 1977 & 23 & Rhodesia 2, UK 1 & 26 & 88 \\
\hline 31 & 1978 & 35 & & 35 & 100 \\
\hline 32 & 1979 & 37 & UK 1 & 38 & 97 \\
\hline 33 & 1980 & 30 & & 30 & 100 \\
\hline 34 & 1981 & 29 & & 29 & 100 \\
\hline 35 & 1982 & 42 & Chile 1, France 1 & 44 & 95 \\
\hline 36 & 1983 & 35 & India 1 & 36 & 97 \\
\hline 37 & 1984 & 40 & India 1 & 41 & 98 \\
\hline 38 & 1985 & 43 & UK 4 & 47 & 91 \\
\hline 39 & 1986 & 49 & Canada 1, USA 1 & 51 & 96 \\
\hline 40 & 1987 & 51 & Germany 1 , UK 1 & 53 & 96 \\
\hline 41 & 1988 & 33 & USA 1 & 34 & 97 \\
\hline 42 & 1989 & 35 & Germany 2, UK 1 & 38 & 92 \\
\hline 43 & 1990 & 30 & Germany 1, UK 1 & 32 & 94 \\
\hline 44 & 1991 & 29 & Swaziland 1 & 30 & 97 \\
\hline 45 & 1992 & 21 & Botswana 1, Swaziland 1, Switzerland 1 & 24 & 88 \\
\hline 46 & 1993 & 16 & & 16 & 100 \\
\hline 47 & 1994 & 14 & China 1, Germany 2, Poland 1 & 18 & 78 \\
\hline
\end{tabular}




\begin{tabular}{|c|c|c|c|c|c|}
\hline 48 & 1995 & 21 & UK 1 , USA 2 & 24 & 88 \\
\hline 49 & 1996 & 10 & Germany 1 , Nigeria 1 & 12 & 83 \\
\hline 50 & 1997 & 31 & Australia 1, China 3, Czech Republic 1, Germany 1, Japan 1, UK 1, USA 1 & 40 & 78 \\
\hline 51 & 1998 & 27 & China 1, Namibia 1, UK 1, USA 2, Zimbabwe 1 & 33 & 82 \\
\hline 52 & 1999 & 24 & Egypt 2, Romania 2. Turkey 1 & 29 & 83 \\
\hline 53 & 2000 & 18 & Australia 1, Germany 1, Nigeria 1, Oman 1, Romania 1, Turkey 1, UK 1, USA 2 & 27 & 67 \\
\hline 54 & 2001 & 9 & Oman 1 & 10 & 90 \\
\hline 55 & 2002 & 12 & Botswana 1, Kenya 1, Romania 1 & 15 & 80 \\
\hline 56 & 2003 & 8 & Austria 1, Botswana 1, Egypt 1, Turkey 1 & 12 & 67 \\
\hline 57 & 2004 & 6 & Algeria 1, Austria 1, China 2, Mauritius 1, UK 1 & 12 & 50 \\
\hline 58 & 2005 & 13 & Botswana 2, China 5, India 1, Kenya 1, Korea 1, Nigeria 1, USA 1 & 25 & 52 \\
\hline 59 & 2006 & 16 & China 2, Cote d'Ivoire 1, India 3, Iran 3, Macedonia 1, Nigeria 2 & 28 & 57 \\
\hline 60 & 2007 & 7 & Algeria 1, China 3, India 6, Iran 4, Kenya 1, Turkey 1 & 23 & 30 \\
\hline 61 & 2008 & 11 & Algeria 1, China 4, Egypt 1, India 5, Iran 4, Romania 1, Turkey 1 & 28 & 39 \\
\hline 62 & 2009 & 18 & China 1, Egypt 1, India 6, Iran 6, Kenya 1, Serbia 1 & 34 & 53 \\
\hline 63 & 2010 & 15 & $\begin{array}{l}\text { China 3, Guyana 1, India 8, Iran 6, Nigeria 1, Tunisia 1, Turkey 2, USA 1, } \\
\text { Zimbabwe } 1\end{array}$ & 39 & 38 \\
\hline 64 & 2011 & 22 & $\begin{array}{l}\text { Belgium 1, Brazil 1, China 3, India 3, Iran 6, Jordan 1, Malaysia 1, Poland 1, } \\
\text { USA 1, Yemen } 1\end{array}$ & 41 & 54 \\
\hline 65 & 2012 & 20 & Algeria 2, Botswana 1, China 4, India 5, Iran 10, Mexico 1, Turkey 1 & 44 & 45 \\
\hline 66 & 2013 & 21 & Botswana 1, China 5, DRC 1, India 2, Iran 11, Nigeria 2, Pakistan 1, Turkey 2 & 46 & 46 \\
\hline 67 & 2014 & 12 & $\begin{array}{l}\text { Botswana 1, China 5, India 6, Iran 7, Lesotho 2, Nigeria 1, Poland 1, Saudi } \\
\text { Arabia 1, Serbia 1, Tanzania 1, Zimbabwe } 1\end{array}$ & 39 & 31 \\
\hline
\end{tabular}




\begin{tabular}{|c|c|c|l|c|c|}
\hline 68 & 2015 & 17 & $\begin{array}{l}\text { Botswana 1, China 2, Ethiopia 1, Iran 7, Kenya 1, Nigeria 2, Pakistan 1, Saudi } \\
\text { Arabia 2 }\end{array}$ & 34 & 50 \\
\hline 69 & 2016 & 20 & Egypt 1, India 1, Iran 5, Nigeria 1, Pakistan 1, Poland 1, USA 1 & 31 & 65 \\
\hline 70 & 2017 & 9 & $\begin{array}{l}\text { Botswana 1, Brazil 1, China 1, Iran 5, Kenya 1, Lesotho 2, Malaysia 1, Mexico } \\
\text { 1, Nigeria 2, Pakistan 1, Saudi Arabia 1, Senegal 1 }\end{array}$ & 27 & 33 \\
\hline 71 & 2018 & 11 & $\begin{array}{l}\text { Algeria 1, China 1, Ethiopia 1, India 2, Iran 1, Kenya 1, Korea 1, Lesotho 1, } \\
\text { Nigeria 2, Pakistan 1, Tanzania 1, Tunisia 1 }\end{array}$ & 25 & 44 \\
\hline
\end{tabular}

